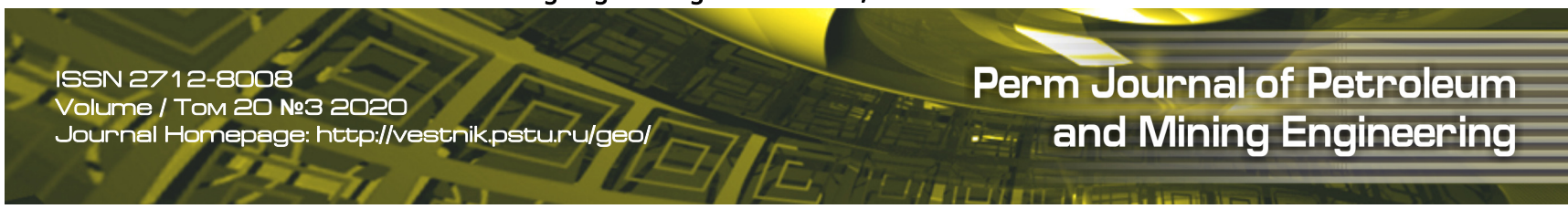

UDC 622.013.364.2

Article / Статья

(c) PNRPU / ПНИПУ, 2020

\title{
International Emission Standards for Mining Machinery and Equipment
}

\section{Mark L. Khazin}

Ural State Mining University (30 Kuybysheva st., Ekaterinburg, 620144, Russian Federation)

Экологические стандарты стран мира для горных машин и оборудования

\section{М.Л. Хазин}

Уральский государственный горный университет (Россия, 620144, г. Екатеринбург, ул. Куйбышева, 30)

\section{Received / Получена: 14.10.2019. Accepted / Принята: 15.06.2020. Published / Опубликована: 17.08.2020}

Keywords.

mining machinery, ecology, open-pit mining, emissions, toxic elements, diesel fuel.

Ключевые слова горные машины, экология, открытые горные работы, выбросы, токсичные элементы, дизельное топливо.
The paper analyses problems associated with the use of mining machinery equipped with diesel engine releases of exhaust gases that have a harmful impact on human health and the environment.

The mining industry uses a wide range of equipment powered by diesel engines: dump trucks, backhoe loaders, drill jumbos and other mining machinery. Engine exhaust gases contain toxic elements that have a significant impact on human health and the environment. Air pollution from gases leads to standbys of mine sites, while a reduced visibility on a route results in a partial or total equipment shutdown. At present, environmental requirements to vehicle engines are a top concern. The problem of air pollution with harmful substances contained in diesel engine exhausts is becoming a global challenge. Solutions of these issues require joint efforts from many countries. International conventions and adoption of relevant standards serve as a means of rapprochement in this sphere.

Most operations in Europe, Asia and America are guided by similar standards as to the content of harmful substances in exhaust gases, the European Union being an influencer in this regard by frequently introducing updates and stringent regulations. Other countries are following this trend and revising their emission standards too. European states had paid attention to this issue earlier than other countries. Today, environmental requirements to vehicle engines are a top priority. Research in this field is focused on such issues as increasing productivity of mining machinery engines, reducing labour costs of maintenance and repairs, enhancing fuel efficiency and significantly improving environmental performance.

Анализируются проблемы, связанные с использованием горных машин, оснащенных дизельными двигателями, выхлопные газы которых оказывают вредное влияние на здоровье человека и окружающую среду.

В горнодобывающей промышленности эксплуатируется огромное количество оборудования с дизельными двигателями: карьерные самосвалы, экскаваторы, буровые станки и другие горные машины. Выхлопные газы двигателей содержат токсичные элементы, оказывающие значительное влияние на здоровье персонала и окружающую среду. Загазованность рабочей атмосферы влечет за собой необходимость остановки карьера, а ухудшение видимости на трассе обусловливает частичную или полную остановку работы оборудования. На сегодняшний день экологические требования к двигателю автомобиля являются приоритетными. Проблема загрязнения атмосферы вредными веществами, содержащимися в выхлопе дизельных двигателей, становится глобальной. Для ее решения требуются совместные усилия многих стран. Инструментом для сближения в данной сфере служат международные конвенции и принятие соответствующих стандартов.

Большинство стран Европы, Азии и Америки ориентируется на сходные нормы по содержанию вредных веществ в выхлопных газах. Евросоюз в этом плане является своеобразным авторитетом: он наиболее часто обновляет данные показатели и внедряет жесткое правовое регулирование. Другие страны следуют такой тенденции и также обновляют нормы выбросов. Европейские страны раньше других обратили внимание на данную проблематику. На сегодняшний день экологические требования к двигателю автомобиля являются приоритетными. Исследования в этой области связаны с такими направлениями, как повышение производительности двигателей горных машин, уменьшение затрат труда на их техническое обслуживание и ремонт, повышение топливной экономичности, значительное улучшение экологических характеристик. 


\section{Introduction}

The mining industry operates a wide range of equipment mainly powered by internal combustion engines: dump trucks, backhoe loaders, drill jumbos and other mining machinery. Enhancing the mining equipment performance and increasing the depth of openpits entail the necessity to adopt increasingly more powerful engines for service vehicles, mostly represented by dump trucks [1-5].

Beside the mining machinery, stationary dieselelectric generator sets notably contribute to environmental pollution from harmful emissions of exhaust gases. Diesel emissions of equipment contain a range of heavy metals (beryllium, cadmium, mercury, etc.) that enter soil, surface and ground waters [6], and have a sizeable effect on the total concentration of black carbon (soot) particles [7, 8].

Exhaust from diesel engines seriously impacts productivity due to increased idle periods resulting from atmospheric gas pollution at openpits, impaired road visibility and deteriorated personnel health [9-12].

Concentrations of harmful gases from mining machinery diesel engines, nonroad and special-service equipment in work areas have become quite threatening due to the specific working conditions involving presence of large numbers of people on a limited site area. At some sites, this leads to a complete stoppage of operations until levels of pollutants in the air and visibility on the roads become normal [4, 9-11]. Additional costs arise for the openpit ventilation $[13,14]$ and personal protective equipment for drivers and other personnel $[15,16]$.

Constant exposure to exhaust gases leads to immunodeficiency, bronchitis, damage to brain vessels, nervous system and other body organs $[17,18]$. Formaldehyde and other hydrocarbons in diesel exhaust gases may cause cancer if exposed thereto over the course of one year. For example, mining workers who had been exposed to diesel engine exhaust gases for 10-20 years were diagnosed with lung cancer [19-21].

The work is intended to analyse the environmental issues of using mining machinery and equipment powered by diesel engines.

\section{Methods}

Service mobile equipment, such as nonroad vehicles and dump trucks, is a main source of air pollution in open pits $[4,3,9,11,22]$. The issue of transport ecological compatibility dates back to the mid-twentieth century, when vehicles became a mass product. European states, located on a relatively small territory, started to introduce various environmental regulations earlier than other countries. Such standards were adopted in individual states and included various requirements to the content of harmful substances in vehicle engine exhaust gases.

As of today, environmental requirements to vehicle engines are a top concern [22-24]. The development of mining machinery engines is focused on increasing their productivity, reducing labour costs of maintenance and repairs, enhancing fuel efficiency and significantly improving environmental performance.

\section{Environmental Standards in the European Union}

For nonroad vehicles, tractors and dump trucks, as well as diesel generator sets, a series of the European Stage standards (Directive $97 / 68 / \mathrm{EC}$ ) is applicable, which regulate the maximum content of four toxic components in exhaust gases: nitrogen oxide $\left(\mathrm{NO}_{\mathrm{x}}\right)$, carbon oxide (CO), hydrocarbons $(\mathrm{CH})$ and solid particles or soot (particulate matter, PM) [25, 26].

The first standard Stage 1 was introduced in 1999. The more stringent regulations of Stage 2 were phased-in from 2001 to 2004, subject to net engine power. Since January 2001, they were applied to $18-37 \mathrm{~kW}$ engines, and then to 130 to $560 \mathrm{~kW}$ diesel engines used in construction and mining machinery weighing from 20 to 100 tons (Table 1).

Reducing sulphur compounds in diesel fuels is a way to improve their environmental performance. Requirements to their content are becoming increasingly restrictive: from 500 million $^{-1}$ in 1996 to 50 million $^{-1}$ in 2005. In 2010, in accordance with European Euro 5 regulations, the sulphur content in petrol and diesel fuel shall not exceed 10 million $^{-1}$ [6].

Stage 3 standards were gradually phased-in between 2006 and 2013, and Stage 4 regulations were introduced in 2014. Further to the engine categories covered by Stage 1 and Stage 2, these standards limit exhaust emissions from railway locomotive and inland watercraft engines. Only new vehicles and equipment fall within the scope of Stage 3-4 regulations (see Table 1), while the use of vehicles already in service may be continued provided the engines comply with Stage 1 and Stage 2. 
Table 1

EU Stage emission standards for nonroad diesel engines

\begin{tabular}{|c|c|c|c|c|c|c|c|}
\hline \multirow[b]{2}{*}{ Standard } & \multirow[b]{2}{*}{ Net engine power, $\mathrm{kW}$} & \multirow[b]{2}{*}{ Category } & \multirow[b]{2}{*}{ Year } & \multicolumn{4}{|c|}{ Content of toxic substances in exhaust gas, $\mathrm{g} /(\mathrm{kWh})$} \\
\hline & & & & $\mathrm{CO}$ & $\mathrm{CH}$ & $\mathrm{NO}_{x}$ & $\begin{array}{c}\text { Particulate } \\
\text { matter }\end{array}$ \\
\hline \multirow{2}{*}{ Stage 1} & $75 \ldots 130$ & - & \multirow{2}{*}{1999} & 5.0 & 1.3 & 9.2 & 0.70 \\
\hline & $130 \ldots 560$ & - & & 5.0 & 1.3 & 9.2 & 0.54 \\
\hline \multirow{2}{*}{ Stage 2} & $75 \ldots 130$ & - & 2003 & 5.0 & 1.0 & 6.0 & 0.3 \\
\hline & $130 \ldots 560$ & - & 2002 & 3.5 & 1.0 & 6.0 & 0.2 \\
\hline \multirow{2}{*}{ Stage $3 \mathrm{~A}$} & $75 . .130$ & $I$ & 2007 & 5.0 & 4.0 & - & 0.3 \\
\hline & $130 \ldots .560$ & $H$ & 2006 & 3.5 & 4.0 & - & 0.2 \\
\hline \multirow{2}{*}{ Stage 3B } & $75 \ldots 130$ & $M$ & 2012 & 5.0 & 0.19 & 3.3 & 0.025 \\
\hline & $130 \ldots 560$ & $L$ & 2011 & 3.5 & 0.19 & 2.0 & 0.025 \\
\hline \multirow{2}{*}{ Stage 4} & $56 \ldots 130$ & $R$ & 2014 & 5.0 & 0.19 & 0.4 & 0.025 \\
\hline & $130 \ldots 560$ & $Q$ & 2014 & 3.5 & 0.19 & 0.4 & 0.025 \\
\hline
\end{tabular}

N o t e: * - Stage 2 also applies to constant-speed engines effective on 31 December 2006.

Stage 4 limits the maximum content of soot (particulate matter) to the range between 0.020 and $0.025 \mathrm{~g} / \mathrm{kWh}$. To comply with these regulations (implying approximately $90 \%$ reduction in toxic contents compared to Stage 2), engine exhaust systems shall be equipped with particulate filters, as it appears. For some engines, exhaust gas aftertreatment may also be required by installation of special systems in the exhaust svstem, such as selective catalvtic reduction (SCR) using ammonia as the reducing agent, to comply with a very stringent $\mathrm{NO}_{x}$ limit of $0.4 \mathrm{~g} / \mathrm{kWh}$ introduced by Stage 4 .

Based on EU directives, national standards are being developed in the member states. Following the European Union, other countries have also introduced equivalent environmental regulations.

\section{Environmental Standards in the USA}

The engines of all vehicles (cars, heavy-duty and nonroad vehicles) in the USA are subject to Tier standards $[25,26]$. The comprehensive character of Tier regulations is reflected even in the adopted engine power classification: 0-18; 19-55; 56-129; 130-560 and over $560 \mathrm{~kW}$, while the European standards cover only diesel engines of 56-129 and 130-560 kW. Each group has its own pollutant emission limits.

The federal Tier 1 regulations for nonroad diesel engines over $37 \mathrm{~kW}$ (50 hp) were adopted in 1994 and phased-in from 1996 to 2000.

In 1996, a Statement of Principles (SOP) regulating the emission standards for nonroad diesel engines was signed between the U.S. Environmental Protection Agency (EPA), the
California Air Resources Board (ARB) and engine manufacturing companies (including Caterpillar, Cummins, John Deere, Detroit Diesel, Deutz, Isuzu, Komatsu, Kubota, Mitsubishi, Navistar, New Holland, Wis-Con, and Yanmar). In 1998, Tier 1 regulations were adopted for equipment under $37 \mathrm{~kW}$ (50 HP) with stricter Tier 2 and Tier 3 regulations (Table 2) for all equipment. The Tier 2 and Tier 3 standards were phased-in from 2000 to 2008.

Engines of all sizes must also comply with smoke standards: $20 \%$ opacity during acceleration, $15 \%$ at lugging, and $50 \%$ in peak mode. The standards provide for several other provisions, such as: averaging, banking and trading of emission credits. as well as maximum limits for emission averaging. 'Family emission limits' (FEL) serve as an average entire engine family's emission standard.

Tier 4 standards (see Table 2) phased-in from 2008 to 2015 provide for a significant reduction in $\mathrm{NO}_{x}$ and particulate matter, as well as stricter restrictions on $\mathrm{CH}$ content. The standards for CO content remained the same as in Tier 2 and Tier 3.

Tier 4 regulations set 'not-to-exceed' (NTE) limits. In most engines. the NTE limits are set at 1.25 times the regular standard for each pollutant. NTE standards apply to engines at the time of certification and throughout the useful life of an engine.

By the specified quantity limits, the latest versions of the US standards correspond to the European regulations (see Tables 1 and 2). As to the limit of sulphur content in diesel fuel, this value was first regulated in Euro 3 and Tier 3 standards. 
Table 2

US Tier emission standards for nonroad diesel engines

\begin{tabular}{|c|c|c|c|c|c|c|c|}
\hline \multirow[b]{2}{*}{ Standard } & \multirow[b]{2}{*}{ Engine power, kW (HP) } & \multirow[b]{2}{*}{ Year } & \multicolumn{5}{|c|}{ Content of toxic substances in exhaust gas, $\mathrm{g} /(\mathrm{kWh})(\mathrm{g} / \mathrm{hph})$} \\
\hline & & & $\mathrm{CO}$ & $\mathrm{CH}$ & $\mathrm{NMHC}+\mathrm{NO}_{x}$ & $\mathrm{NO}_{x}$ & $\begin{array}{c}\text { Particulate } \\
\text { matter }\end{array}$ \\
\hline Tier 1 & \multirow{3}{*}{$75 \ldots 130(100 \ldots 175)$} & 1997 & - & - & - & $9.2(6.9)$ & - \\
\hline Tier 2 & & 2003 & $5.0(3.7)$ & - & $6.6(4.9)$ & - & $0.30(0.22)$ \\
\hline Tier 3 & & 2007 & $5.0(3.7)$ & - & $4.0(3.0)$ & - & $-*$ \\
\hline Tier 1 & \multirow{3}{*}{$130 \ldots 225(175 \ldots 300)$} & 1996 & $11.4(8.5)$ & $1.3(1.0)$ & - & $9.2(6.9)$ & $0.54(0.40)$ \\
\hline Tier 2 & & 2003 & $3.5(2.6)$ & - & $6.6(4.9)$ & - & $0.20(0.15)$ \\
\hline Tier 3 & & 2006 & $3.5(2.6)$ & - & $4.0(3.0)$ & - & $-*$ \\
\hline Tier 1 & \multirow{3}{*}{$225 \ldots 450(300 \ldots 600)$} & 1996 & $11.4(8.5)$ & $1.3(1.0)$ & 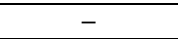 & $9.2(6.9)$ & $0.54(0.40)$ \\
\hline Tier 2 & & 2001 & $3.5(2.6)$ & - & $6.4(4.8)$ & - & $0.20(0.15)$ \\
\hline Tier 3 & & 2006 & $3.5(2.6)$ & - & $4.0(3.0)$ & - & - \\
\hline Tier 1 & \multirow{3}{*}{$450 \ldots 560(600 \ldots .750)$} & 1996 & $11.4(8.5)$ & - & - & $9.2(6.9)$ & $0.54(0.40)$ \\
\hline Tier 2 & & 2002 & $3.5(2.6)$ & - & $6.4(4.8)$ & - & $0.20(0.15)$ \\
\hline Tier 3 & & 2006 & $3.5(2.6)$ & - & $4.0(3.0)$ & - & $-{ }^{* *}$ \\
\hline Tier 1 & \multirow{2}{*}{ Over 560 (over 750) } & 2000 & $11.4(8.5)$ & $1.3(1.0)$ & - & $9.2(6.9)$ & $0.54(0.40)$ \\
\hline Tier 2 & & 2006 & $3.5(2.6)$ & - & $6.4(4.8 /)$ & - & $0.20(0.15)$ \\
\hline \multirow{3}{*}{ Tier 4} & $56 \ldots 130(75 \ldots 175)$ & $2012-2014$ & $5.0(3.7)$ & $0.19(0.14)$ & - & $0.4(0.3)$ & $0.02(0.015)$ \\
\hline & $130 \ldots 560(175 \ldots 750)$ & 2011-2014 & $3.5(2.6)$ & $0.19(0.14)$ & - & $0.4(0.3)$ & $0.02(0.015)$ \\
\hline & Over 900 (1223) & 2014 & $3.5(2.6)$ & $0.40(0.30)$ & - & $3.5(2.6)$ & $0.10(0.07)$ \\
\hline Tier 4 Final & $130 \ldots .560(175 \ldots 750)$ & - & $3.5(2.6)$ & $0.19(0.14)$ & - & $0.4(0.3)$ & $0.02(0.015)$ \\
\hline
\end{tabular}

N o t e : * not adopted; engines must meet Tier 2 PM standard; NMHC - non-methane hydrocarbons.

Table 3

$\mathrm{RF}$ emission standards for nonroad diesel engines

\begin{tabular}{|c|c|c|c|c|c|c|}
\hline \multirow[t]{2}{*}{ Standard } & \multirow[t]{2}{*}{ Power range } & Net engine power, kW & $\mathrm{CO}$ & $\mathrm{CH}$ & $\mathrm{NO}_{x}$ & $\begin{array}{l}\text { Particulate } \\
\text { matter (PM) }\end{array}$ \\
\hline & & \multicolumn{5}{|c|}{$\mathrm{g} /(\mathrm{kWh})$} \\
\hline \multirow{2}{*}{ GOST P 41.96-99 } & - & $75 \leq P<130$ & 5 & 1.3 & 9.2 & 0.70 \\
\hline & - & $P \geq 130$ & 5 & 1.3 & 9.2 & 0.54 \\
\hline \multirow{4}{*}{ GOST P 41.96-05 } & - & $75 \leq P<130$ & 5 & 1.3 & 9.2 & 0.70 \\
\hline & - & $P \geq 130$ & 5 & 1.3 & 9.2 & 0.54 \\
\hline & $\mathrm{F}^{*}$ & $75 \leq P<130$ & 5.0 & 1.0 & 6.0 & 0.3 \\
\hline & $E^{*}$ & $130 \leq P \leq 560$ & 3.5 & 1.0 & 6.0 & 0.2 \\
\hline \multirow{2}{*}{ GOST P 41.96-11 } & $\mathrm{F}$ & $75 \leq P<130$ & 5.0 & 1.0 & 6.0 & 0.3 \\
\hline & E & $130 \leq P \leq 560$ & 3.5 & 1.0 & 6.0 & 0.2 \\
\hline
\end{tabular}

\section{Environmental Standards in Russia}

In general, Russia keeps up with the EU emission standards. Environmental standards for heavy-duty nonroad equipment are regulated by GOST national standards [27-29]. The first standard GOST R41 96-99, equivalent to Stage I (Tier 1), was adopted in 1999, with subsequent, stricter regulations introduced by GOST R41 9605 and GOST R41 96-11 (Table 3).

On 27 February 2008, a Technical Regulation was approved by Resolution No. 118 of the Government of the Russian Federation (as amended by Resolution No. 1076 of 30 December 2008), and came into effect on 27 August 2008, having established the diesel fuel sulphur content in the range between 10 and $500 \mathrm{ppm}$ depending on the class. However, the diesel fuel containing $2,000 \mathrm{ppm}$ of sulphur may be available on the market for approximately three years (from 2011 to 2014, the dates vary for different fuel types, and this period is not limited for type 5 fuels). The use of low-grade diesel fuel dismissed in all developed countries, will therefore continue for quite a few years. Many openpits in Russia still use dump trucks, backhoe loaders and drill jumbos manufactured in the 1990s and equipped with engines of domestic make that fail to meet the latest world standards and stand at Stage 1-2. Outdated diesel fuel grades are better suited for such equipment and cost less.

\section{Environmental Standards in North and South America}

Canada [251. On-Road Vehicle and Engine Emission Regulations (SOR/2003-2) are harmonised with the US standards, but with some 
lagging behind, which entails a discrepancy between the standards of Canada and the US during the transition phase.

Mexico [251. The first emission standards for heavy-duty diesel engines NOM-044-ECOL-1993 became effective in 1993. These standards were based on the US environmental regulations. Since February 2003, as an alternative, engines may also comply with the European standards. In 2006, new emission standards for heavy-duty truck engines were adopted, complying with US 2004 standards or equivalent to Euro 4. In 2018, the emission standards were aligned with Tier 5/Euro 5.

In South America [25], the regulatory framework limiting harmful diesel engine emissions is also based on the European and US standards.

Argentina. Engine emission standards for heavy-duty nonroad equipment are based on the European regulations.

In Brazil, the first standard was adopted in 1988. Most of these standards were equivalent to European regulations, yet the current PROCONVE L6 standard, although compliant with Euro 5, fails to stipulate the mandatory particulate matter or air emissions filters.

Chile. Where dual standards exist, engines must meet either the EU or the US requirements.

Peru. As of 1 January 2003, all new heavyduty engines must comply with the Euro 2 standard, and with the Euro 3 standard effective since 2007.

\section{Environmental Standards in Asia}

In Asia [25], the regulatory framework for normalising diesel engine emissions is based on a combination of the European and the US standards, subject to regional specifics.

In China, vehicle emission control programmes were first introduced in the 1980s, and a nationwide standard (CNS) was adopted in the late 1990s. China has gradually been implementing stricter exhaust emission standards for cars and heavy-duty trucks in line with the European regulations. China 1 standard followed Euro 1, China 2 was based on Euro 2, etc. These standards have already been introduced in major cities such as Beijing, Shanghai and Guangzhou $[30,31]$. China 5 is the applicable national standard regulating the content of toxic substances in vehicle exhaust emissions in China. The Ministry of Environmental Protection is focused on developing China 6, a new standard regulating the content of harmful substances in exhaust gases. China 5 and 6 regulations are identical for all fuels and are more stringent compared to Euro 6.

Japan has its own regulatory framework that limits harmful emissions from diesel engines. The latest version of the 2009 standards stands between Tier 4 and Euro 5. Under these regulations, the limits for nitrogen oxide emissions from 56 to $560 \mathrm{~kW}$ diesel engines must be reduced to $0.4 \mathrm{~g} / \mathrm{kWh}$. For engines between 56 and $130 \mathrm{~kW}$, the standards were introduced in 2015, while more powerful diesel engines were affected as early as in 2014. MOT/MOC standards were developed for nonroad diesel and generator set engines and are mostly aligned to the European Stage 4 and the US Tier 4 regulations. Furthermore, all vehicles in Japan are affected by the 'fuel efficiency target' programme. This is the world's first program to cover not only cars, but also heavy-duty vehicles. Diesel fuel in Japan is affected by 'The Law On Quality Control of Gasoline and Other Fuels' and the industrial standard K 2204 'Diesel Fuel'.

India started adopting European emission and fuel regulations for light-duty and heavy-duty vehicles since 2000. Bharat Stage 3 standard is effective nationwide, while Delhi and 11 other major cities have already adopted Bharat Stage 4 regulations.

In Malaysia, Indonesia, the Philippines, Vietnam and Thailand, Euro 2 standards are still in force.

EU Stage 5 emission standards for nonroad diesel \& generator set engines

\begin{tabular}{|c|c|c|c|c|c|c|c|}
\hline \multirow{2}{*}{ Engine type } & \multirow{2}{*}{$\begin{array}{l}\text { Net power } \\
\text { range, kWh }\end{array}$} & \multirow{2}{*}{$\begin{array}{c}\text { Date } \\
\text { of introduction }\end{array}$} & \multicolumn{5}{|c|}{ Content of toxic substances in exhaust gas, $\mathrm{g} /(\mathrm{kWh})$} \\
\hline & & & $\mathrm{CO}$ & $\mathrm{CH}$ & $\mathrm{NO}_{X}$ & $\mathrm{PM}$ & $\mathrm{PN}, 1 / \mathrm{kWh}$ \\
\hline$\overline{\text { All }}$ & $130 \ldots 560$ & 2019 & 3.5 & $0.19^{c}$ & 0.4 & 0.015 & $1 \cdot 10^{12}$ \\
\hline$\overline{\text { All }}$ & $>560$ & 2019 & 3.5 & $0.19^{d}$ & 3.5 & 0.045 & - \\
\hline Generator sets & $>560$ & 2019 & 3.5 & $0.19^{\mathrm{a}}$ & 0.67 & 0.035 & - \\
\hline
\end{tabular}


South Korea. Earlier emission regulations for heavy-duty diesel truck engines were based on Japanese regulations and follow European standards since 2003. Korea's first nonroad vehicle emission regulations came into force in 2004-2005 based on the US Tier 1 and Tier 2 standards. Emission standards based on the US Tier 3 requirements became effective in 2009 for construction machinery and in 2013 for agricultural equipment, while the Tier 4-based standard became effective from 2015.

In Asia, all environmental regulations as to the content of pollutants in exhaust gases also apply to diesel fuel, assuming a gradual reduction in its content of sulphur. Only in China, the adopted standards fail to apply to diesel fuel used for nonroad vehicles and generator sets.

\section{Environmental Standards in other Countries}

Most of the other countries adopt the standards introduced in the USA, Europe or Japan [25].

Australia and New Zealand apply Euro regulations that became effective almost concurrently with the European countries. European, American or Japanese certificates are valid in certain countries, which depends on the economic and political relations between the governments. Therefore, as of today, nonroad equipment and generator set engines are subject to regulations equivalent to Stage II standard in most countries.

\section{Comparison of Environmental Standards}

The EU Stage 4 and US Tier 4 Final standards are the latest environmental regulations in effect to limit harmful emissions from nonroad vehicle engines. They are comparable in classification and limit values, so that there is no need to produce different engines for each market in the context of globalisation.

However, the European Union is drafting new, more stringent emission regulations - Stage 5 [32-34] (Table 4), in compliance with the US Tier 5 standard.

The proposed Stage 5 standard will replace an existing, multilayered legal framework in the EU with one overarching regulation.

Stage 4 standard now applies to engines between 56 and $560 \mathrm{~kW}$, and all generator sets will fall within the scope of Stage 5, regardless of power: under $19 \mathrm{~kW}$ and over $560 \mathrm{~kW}$.
Of great concern to scientists is the particulate matter (PM) release by diesel engines. In its pure form, soot is non-toxic. However, the soot particles have a high adsorption capacity and carry toxic substances on their surface. Most hazardous are nanoparticles with a diameter of less than $50 \mathrm{~nm}$ that penetrate deeply into human lungs and contribute to the development of cardiovascular and cancer diseases [7, 17, 35, 36]. Soot may remain suspended in the air for a long time, thus extending the exposure time of toxic substances $[6,8]$. Newer, more advanced models of diesel engines release fine particles in higher amounts compared to those made with the old technology [37].

In October 2014, the European Commission adopted the 'Fuel Quality Directive' that obliges fuel suppliers to reduce greenhouse gas intensitv of transport fuels bv a minimum of $6 \%$ by 2020 [38]. Stage 5 regulation will therefore introduce
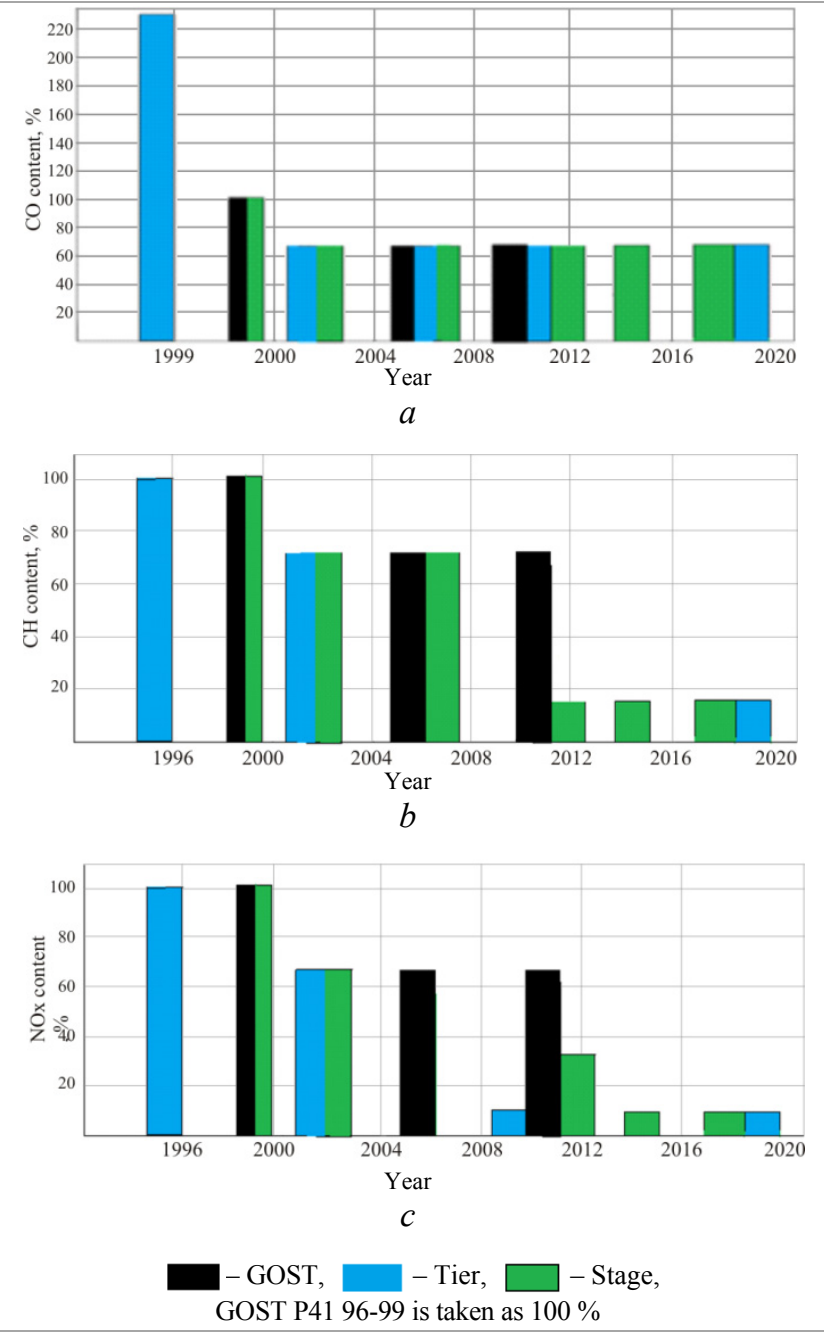

Fig. 1. Dynamics of changes in environmental content requirements: $a-\mathrm{CO} ; b-\mathrm{CH} ; c-\mathrm{NO}_{x}$ 


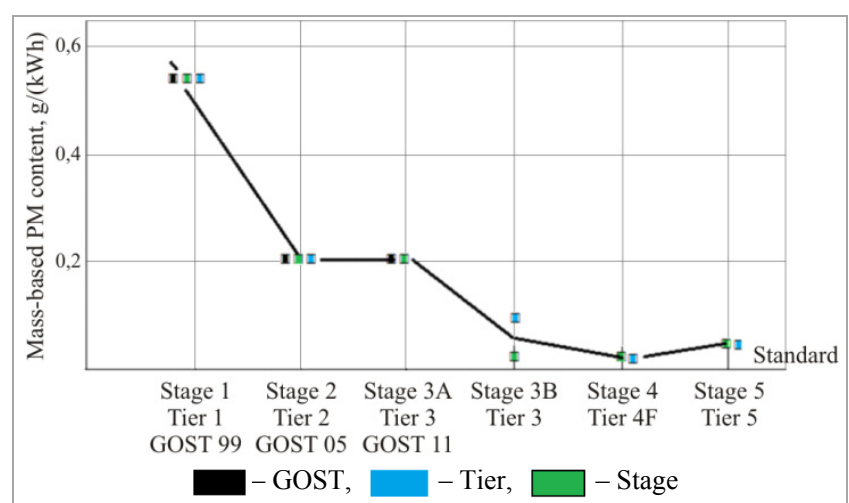

Fig. 2. Change in PM content of diesel engine combustion gas by standards

the latest restrictions on the mass-based PM, particle number $(\mathrm{PN})$ and $\mathrm{NO}_{x}$ emission limits in engine exhaust gases (see Table 4). The PN limit was introduced to force the use of filtering technologies for particulate matter (soot), such as active (controlled) regeneration filters, on all engines covered by these standards.

It should be noted that fundamental changes shall be introduced to the US environmental standards to harmonise Stage 5 with Tier 5 . The point is that Stage 5 sets a PN limit in emissions and forces to install a diesel particulate filter (DPF) to meet these requirements, whereas Tier 4 standards can be met without it.

Environmental protection is one of mankind paramount concerns, as human lives, health and well-being depend on its solution. In the context of globalisation, the issue of air pollution by harmful substances from car exhausts is no longer relevant for developed countries only, but is becoming a global issue that requires joint efforts from many countries. The environmental requirements to engine and fuel quality are therefore increasingly tightening (Figure 1).

The US Tier 4 and Tier 4 Final regulations correspond to lower particle number limits for nonroad engines compared to the EU Stage 3B and 4, respectively. However, the US standards fail to require the use of diesel particulate filters. EU Stage V proposes a new, lower limit of particulate matter (reaching $0.015 \mathrm{~g} / \mathrm{kWh}$ for engines between $130 \mathrm{~kW}$ and $560 \mathrm{~kW}$ ). This is $25 \%$ lower than the Tier 4 Final requirement. The particulate matter content limits, as well as the new PN requirements proposed by the $\mathrm{EU}$, will increase the likelihood of diesel particulate filters being used to significantly reduce soot emissions from nonroad engines in the power range between 19 and $560 \mathrm{~kW}[25,39]$. The proposed Stage V nonroad engine standard may be a new best practice for the rest of the world to follow.

The PM limit of Stage 5 is $97 \%$ lower than that of Stage 1, and the the hydrocarbon $(\mathrm{CH})+$ nitrogen oxides $\left(\mathrm{NO}_{X}\right)$ limit is $94 \%$ lower (Figure 2). Using diesel NRE engines in the range between 130 and $560 \mathrm{~kW}$, the PM limit is lowered to $0.015 \mathrm{~g} / \mathrm{kWh}$, i.e. a reduction of $40 \%$ compared to the previous Stage 4 limit $(0.025 \mathrm{~g} / \mathrm{kWh})$.

The increase in the PN limit of Stage 5 (Tier 5) standards is due to the fact that previous standards applied to engines under $560 \mathrm{~kW}$, while Stage 5 (Tier 5) covers engines over $560 \mathrm{~kW}$.

Harmonisation of engine emission regulations between countries is stipulated by rapidly developing international economic relations, as well the necessity to stand up for purity of environment.

The EU has adopted a series of seven directives over the past two decades to address emissions from non-road engines. Current EU regulation of emissions from these engines consists of various annexes that have been amended eight times since adoption in 1997. These directives left it up to individual EU member states to modify standards to achieve the intended outcomes, which resulted in 28 national standards currently in effect.

In addition to the 28 national laws, regional amendments set supplementary requirements on the engines sold and used in targeted areas, reflecting more stringent requirements than European law. For example, Germany [40], Austria [41] and the Netherlands [42] have adopted national standards requiring mandatory diesel particulate filters on heavy-duty construction equipment.

\section{Conclusions}

Human health and the environmental protection are paramount for the mankind. The problem of air pollution from combustion gases from mining and nonroad vehicles in the context of globalisation is no longer applicable to individual countries only, but is becoming a universal concern. The joint efforts of many countries are therefore being a requisite. Being an influencer in this regard, the European Union frequently introduces updates and stringent regulations. Most countries are guided by similar exhaust gas pollutant content regulations, follow the trend and update their emission standards. 


\section{References}

1. Humphreys D. Mining productivity and the fourth industrial revolution. Mineral Economics, 2019, pp. 1-11. DOI.org/10.1007/sl 3563-019-00172-9

2. Burmistrov K.V., Osintsev N.A., Shakshakpaev A.N. Selection of Open-Pit Dump Trucks during Quarry Reconstruction. Procedia Engineering, 2017, vol. 206, pp. 1696-1702. DOI.org/10.1016/j.proeng.2017.10.700

3. Da Cunha Rodovalho E., Lima H. M., De Tomi G. New approach for reduction of diesel consumption by comparing different mining haulage configurations. Journal of environmental management, 2016, vol. 172, pp. 177-185. DOI.org/10.1016/j.jenvman.2016.02.048

4. Koptev V.Y., Kopteva A.V. Developing an Ecological Passport for an Open-Pit Dump Truck to Reduce Negative Effect on Environment. IOP Conference Series: Earth and Environmental Science. IOP Publishing, 2017, vol. 66, no. 1, 012009 p. DOI: 10.1088/1755-1315/66/1/012009

5. Jacobs W., Hodkiewicz M.R., Bräunl T. A Cost-Benefit Analysis of Electric Loaders to Reduce Diesel Emissions in Underground Hard Rock Mines. IEEE Transactions on industry applications, 2015, vol. 51, no. 3, pp. 2565-2573. DOI: 10.1109/TIA.2014.2372046

6. Boichenko S.V., Shkil'niuk I.A. Ekologicheskie aspekty ispol'zovaniia motornykh topliv (Obzor) [Environmental aspects of the use of motor fuels (Review)]. Energotekhnologii $i$ resursosberezhenie, 2014, no. 5-6, pp. 35-44.

7. Nikiforova V.A., Vidishcheva E.A., Vidishcheva D.D., Gleba V.S. Analiz vliianiia vybrosov avtotransporta na uroven' zagriazneniia atmosfernogo vozdukha: regional'nyi aspekt [Analysis of the Impact of Vehicle Emissions on the Level of Air Pollution: Regional Aspect]. Ustoichivoe razvitie regionov Rossii: ot strategii $\mathrm{k}$ taktike, 2017, pp. 114-119.

8. Kholod N.M., Malyshev V.S., Evans M. Snizhenie vybrosov chernogo ugleroda kar'ernymi samosvalami [Minimizing the black carbon emission of mine dump trucks]. Gornaia promyshlennost', 2015, no. 3 (121), pp. 72-76.

9. Khazin M.L., Tarasov P.I., Furzikov V.V., Tarasov A.P. Ekologo-ekonomicheskaia otsenka ispol'zovaniia kar'ernykh samosvalov [Environmental and technical assessment of operation of career dump trucks in northern areas]. Izvestiia vysshikh uchebnykh zavedenii. Gornyi zhurnal, 2018, no. 7, pp. 85-94. DOI: 10.21440/0536-1028-2018-7

10. Sheshko O.E. Ekologo-ekonomicheskoe obosnovanie vozmozhnosti snizheniia nagruzki na prirodnuiu sredu ot kar'ernogo transporta [Ecological and economic substantiation of the possibility to reduce the load on the nature environment from open pit transport]. Gornyi informatsionno-analiticheskii biulleten' (nauchnotekhnicheskii zhurnal), 2017, no. 2, pp. 241-252.

11. Khazin M.L., Tarasov A.P. Ekologo-ekonomicheskaia otsenka kar'ernykh trolleivozov [Ecological and economic evaluation of quarry trolley trucks]. Vestnik Permskogo natsional'nogo issledovatel'skogo politekhnicheskogo universiteta. Geologiia. Neftegazovoe i gornoe delo, 2018, vol. 17, no. 2, pp. 66-80. DOI: 10.15593/2224-9923/2018.2.6

12. Dallmann T., Menon A. Technology pathways for diesel engines used in non-road vehicles and equipment. International Council on Clean Transportation (ICCT). Washington, DC, USA, 2016.

13. Kozyrev S.A., Amosov P.V. Puti normalizatsii atmosfery glubokikh kar'erov [Ways of atmosphere normalization of deep open-pits]. Vestnik Murmanskogo gosudarstvennogo tekhnicheskogo universiteta, 2014, vol. 17, no. 2, pp. 231-237.

14. Starostin I.I., Bondarenko A.V. Provetrivanie kar'erov struinymi ventiliatorami v komplekse s ustroistvom dlia aeratsii [Jet Fans Airing Quarries in Combination with a Device for Aerating]. Nauka $i$ obrazovanie: nauchnoe izdanie Moskovskogo gosudarstvennogo tekhnicheskogo universiteta imeni N.E. Baumana, 2015, no. 1, pp. 32-41. DOI: 10.7463/0115.0755210

15. Kuleshov A.N., Andreev L.N. Vliianie parametrov mikroklimata salonov gruzovykh avtomobilei na usloviia truda i metody ego uluchsheniia [Influence of parameters of microclimate of interiors of trucks on working conditions and methods of its improvement]. Sovremennye tendentsii razvitiia nauki $i$ tekhnologii, 2016, no. 12-3, pp. 68-71.

16. Kutenev V.F., Saikin A.M. Issledovanie vliianiia uslovii ekspluatatsii kar'ernykh samosvalov na zagriaznenie vozdukha kabin voditelei [Research of impact service conditions of career dump trucks on air pollution in cabins of drivers]. Zhurnal avtomobil'nykh inzhenerov, 2009, no. 4 (57), pp. 17-19.

17. Kachuri L., Villeneuve P.J., Parent M-É., Johnson K.C. Workplace exposure to diesel and gasoline engine exhausts and the risk of colorectal cancer in Canadian men. Environmental Health, 2016, vol. 15, no. 1, pp. 4-16. DOI.org/10.1186/s12940-016-0088-1

18. Taxell P., Santonen T. Diesel engine exhaust: basis for occupational exposure limit value. Toxicological Sciences, 2017, vol. 158, no. 2, pp. 243-251. DOI.org/10.1093/toxsci/kfx110

19. Thiruvengadam A., Besch M., Carder D., Oshinuga A. Unregulated greenhouse gas and ammonia emissions from current technology heavy-duty vehicles. Journal of the Air \& Waste Management Association, 2016, vol. 66, no. 11, pp. 1045-1060. DOI.org/10.1080/10962247.2016.1158751.

20. Neumeyer-Gromen A., Razum O., Kersten N., Seidler A., Zeeb H. Diesel motor emissions and lung cancer mortalityResults of the second follow-up of a cohort study in potash miners. International journal of cancer, 2009, vol. 124, no. 8, pp. 1900-1906. DOI.org/10.1002/ijc.24127

21. Peters C.E., Parent M.É., Harris S.A. et al. Occupational Exposure to Diesel and Gasoline Engine Exhausts and the Risk of Kidney Cancer in Canadian Men. Annals of work exposures and health, 2018, vol. 62, no. 8, p. 978-989. DOI.org/10.1093/annweh/wxy059

22. Osorio-Tejada J.L., Llera-Sastresa E., Scarpellini S. A multi-criteria sustainability assessment for biodiesel and liquefied natural gas as alternative fuels in transport systems. Journal of Natural Gas Science and Engineering, 2017, vol. 42, pp. 169-186. DOI: org/10.1016/j.jngse.2017.02.046

23. Frey H.C. Trends in on road transportation energy and emissions. Journal of the Air \& Waste Management Association, 2018, vol. 68, no. 6, pp. 514-563. DOI: 10.1080/10962247.2018.1454357

24. Quiros D.C., Smith J., Thiruvengadam A., Huai T. Greenhouse gas emissions from heavy-duty natural gas, hybrid, and conventional diesel on-road trucks during freight transport. Atmospheric Environment, 2017, vol. 168, pp. 36-45. DOI.org/10.1016/j.atmosenv.2017.08.066

25. Emission Standards, available at: https://www. dieselnet.com/standards/ (accessed 19 August 2019).

26. EU: Nonroad Engines, available at: https:// www.dieselnet. com/standards/eu/nonroad.php\#intro (accessed 19 August 2019).

27. GOST R 41.96-1999. Edinoobraznye predpisaniia, kasaiushchiesia dvigatelei $\mathrm{s}$ vosplameneniem ot szhatiia, prednaznachennykh dlia ustanovki na sel'skokhoziaistvennykh i lesnykh traktorakh i vnedorozhnoi tekhnike, $\mathrm{v}$ otnoshenii vybrosa vrednykh veshchestv etimi dvigateliam. Vved. 2001-01-01 [GOST R 41.96-1999. Uniform regulations for compression ignition engines for agricultural and forestry tractors and off-road equipment regarding the emission of harmful substances from these engines. Enter. 2001-01-01]. Moscow: Izdatel'stvo standartov, 2001, $61 \mathrm{p}$.

28. GOST R 41.96-2005. Edinoobraznye predpisaniia, kasaiushchiesia vigatelei s vosplameneniem ot szhatiia, prednaznachennykh dlia ustanovki na sel'skokhoziaistvennykh i lesnykh traktorakh i vnedorozhnoi tekhnike, $\mathrm{v}$ otnoshenii vybrosa vrednykh veshchestv etimi dvigateliam. Vved. 2008-01-01 [GOST R 41.96-2005. Uniform regulations for compression ignition engines for agricultural and forestry tractors and offroad vehicles with regard to the emission of harmful substances from these engines. Enter. 2008-01-01]. Moscow: Standartinform, 2006, 61 p.

29. GOST R 41.96-2011. Edinoobraznye predpisaniia, kasaiushchiesia dvigatelei s vosplameneniem ot szhatiia, prednaznachennykh dlia ustanovki na sel'skokhoziaistvennykh i lesnykh traktorakh i vnedorozhnoi tekhnike, $\mathrm{v}$ otnoshenii vybrosa vrednykh veshchestv etimi dvigateliam. Vved. 2013-01-03 vzamen GOST R 41.96-2005 [GOST R 41.96-2011. Uniform regulations for compression ignition engines for agricultural and forestry tractors and offroad equipment regarding the emission of harmful substances from these 
engines. Enter. 2013-01-03 instead of GOST R 41.96-2005]. Moscow: Standartinform, 2013, $61 \mathrm{p}$.

30. Song H., Ou X., Yuan J., Wang C.l. Energy consumption and greenhouse gas emissions of diesel/LNG heavy-duty vehicle fleets in China based on a bottom-up model analysis. Energy, 2017, vol. 140, pp. 966-978. DOI.org/10.1016/j.energy.2017.09.011

31. Xing Y., Song H., Yu M. et al. The characteristics of greenhouse gas emissions from heavy-duty trucks in the BeijingTianjin-Hebei (BTH) region in China. Atmosphere, 2016, vol. 7, no. 9, pp. 121-132. DOI.org/10.3390/atmos7090121

32. European Commission, "Cutting emissions and cutting red tape: a new regulation for off-road engines" (2014), available at: http://europa.eu/rapid/press-release_IP-14-1044_en.htm (accessed 19 August 2019).

33. European Parliament and Council. "Regulation (EU) 2016/1628 of the European Parliament and of the Council of 14 September 2016 on requirements related to gaseaous and particulate pollution emission limits and type-approval for internal combustion engines for non-road mobile machinery" (2016), available at: http://eur-lex.europa.eu/legal-content/EN/TXT/?uri= CELEX:32016 R1628 (accessed 19 August 2019).

34. Shao Z., Dallmann T. European stage v non-road emission standars, available at: https://theicct.org/ publications/european-stage-vnon-road-emission-stan-dards (accessed 19 August 2019).

35. Yoon S., Quiros D.C., Dwyer H.A., Collins J.F. Characteristics of particle number and mass emissions during heavy-duty diesel truck parked active DPF regeneration in an ambient air dilution tunnel. Atmospheric Environment, 2015, vol. 122, pp. 58-64. DOI.org/10.1016/j.atmosenv.2015.09.032

36. Yamada $\mathrm{H}$., Inomata $\mathrm{S}$., Tanimoto $\mathrm{H}$. Mechanisms of increased particle and VOC emissions during DPF active regeneration and practical emissions considering regeneration. Environmental science \& technology, 2017, vol. 51, no. 5, pp. 2914-2923. DOI.org/10.1021/acs.est.6b05866

37. Chernetsov D.A. Toksichnost' otrabotavshikh gazov dizelei $\mathrm{i}$ ikh antropogennoe vozdeistvie [Diesel exhaust gas toxicity and their anthropogenic impact]. Voprosy sovremennoi nauki $i$ praktiki. Universitet imeni V.I. Vernadskogo, 2010, no. 10-12, pp. 54-59.

38. European Commission, Climate action: Reducing the carbon content of transport fuels: press release. Brussels, 2014.

39. Cottrell J. FPT Powertrain Technologies Stage V NRMM. $8^{\circ}$ Integer Chicago; DEUTZ. Stage V ready (2015), \& Rolls-Royce power systems AG. "Rolls-Royce to exhibit MTU Stage V engines at bauma 2016 (2016), available at: http://www.oemoffhighway.com/ press_release/12160037/ rolls-royce-to-exhibit-mtu-stage-v-enginesat-bauma-201 (accessed 19 August 2019).

40. Federal Institute for Occupational Safety and Health (BAuA). «Technische Regel für Gefahrstoffe 554» (2008), available at: http://www.baua.de/de/Themen-von-A-Z/Gefahrstoffe/TRGS/TRGS554.html (accessed 19 August 2019).

41. The Austrian Federal Ministry of Agriculture, Forestry, Environment and Water Management. «Verordnung über die Verwendung von mobilen technischen Einrichtungen, Maschinen und Geräten» (2015), available at: https://www.bmlfuw.gv.at/umwelt/luftlaerm-erkehr/luft/ richtlinien/offroad-vo.html (accessed 19 August 2019).

42. The Inspectorate SZW, available at: http://www. inspectieszw.nl (accessed 19 August 2019).

\section{Библиографический список}

1. Humphreys D. Mining productivity and the fourth industrial revolution // Mineral Economics. - 2019. - P. 1-11. DOI.org/10.1007/sl 3563-019-00172-9

2. Burmistrov K.V., Osintsev N.A., Shakshakpaev A.N. Selection of Open-Pit Dump Trucks during Quarry Reconstruction // Procedia Engineering. - 2017. - Vol. 206. - P. 1696-1702. DOI.org/10.1016/j.proeng.2017.10.700

3. Da Cunha Rodovalho E., Lima H. M., De Tomi G. New approach for reduction of diesel consumption by comparing different mining haulage configurations // Journal of environmental management. - 2016. - Vol. 172. - P. 177-185. DOI.org/10.1016/j.jenvman.2016.02.048

4. Koptev V.Y., Kopteva A.V. Developing an Ecological Passport for an Open-Pit Dump Truck to Reduce Negative Effect on Environment // IOP Conference Series: Earth and Environmental Science. - IOP Publishing. - 2017. - Vol. 66, № 1. P. 012009. DOI: 10.1088/1755-1315/66/1/012009

5. Jacobs W., Hodkiewicz M.R., Bräunl T. A Cost-Benefit Analysis of Electric Loaders to Reduce Diesel Emissions in Underground Hard Rock Mines // IEEE Transactions on industry applications. - 2015. - Vol. 51, № 3. - P. 2565-2573. DOI: 10.1109 /TIA.2014.2372046

6. Бойченко С.В. Шкильнюк И.А. Экологические аспекты использования моторных топлив (Обзор) // Энерготехнологии и ресурсосбережение. - 2014. - № 5-6. - С. 35-44.

7. Анализ влияния выбросов автотранспорта на уровень загрязнения атмосферного воздуха: региональный аспект / В.А. Никифорова, Е.А. Видищева, Д.Д. Видищева, В.С. Глеба // Устойчивое развитие регионов России: от стратегии к тактике. - Новосибирск, 2017. - С. 114-119.

8. Холод Н.М., Малышев В.С., Эванс М. Снижение выбросов черного углерода карьерными самосвалами // Горная промышленность. - 2015. - № 3 (121). - С.72-76.

9. Эколого-экономическая оценка использования карьерных самосвалов / М.Л. Хазин, П.И. Тарасов, В.В. Фурзиков, А.П. Тарасов // Известия высших учебных заведений. Горный журнал. - 2018. - № 7. - С. 85-94. DOI: 10.21440/0536-1028-2018-7

10. Шешко О.Е. Эколого-экономическое обоснование возможности снижения нагрузки на природную среду от карьерного транспорта // Горный информационноаналитический бюллетень (научно-технический журнал). 2017. - № 2. - С. 241-252.

11. Хазин М.Л., Тарасов А.П. Эколого-экономическая оценка карьерных троллейвозов // Вестник Пермского национального исследовательского политехнического университета. Геология. Нефтегазовое и горное дело. - 2018. T. 17, № 2. - C. 66-80. DOI: 10.15593/2224-9923/2018.2.6

12. Dallmann T., Menon A. Technology pathways for diesel engines used in non-road vehicles and equipment // International Council on Clean Transportation (ICCT). Washington, DC, USA, 2016.

13. Козырев С.А., Амосов П.В. Пути нормализации атмосферы глубоких карьеров // Вестник Мурманского государственного технического университета. - 2014. - Т. 17, № 2. - С. 231-237.

14. Старостин И.И., Бондаренко А.В. Проветривание карьеров струйными вентиляторами в комплексе с устройством для аэрации // Наука и образование: научное издание МГТУ им. Н.Э. Баумана. - 2015. - № 1. - С. 32-41. DOI: 10.7463/0115.0755210

15. Кулешов А.Н., Андреев Л.Н. Влияние параметров микроклимата салонов грузовых автомобилей на условия труда и методы его улучшения // Современные тенденции развития науки и технологий. - 2016. - № 12-3. - С. 68-71.

16. Кутенев В.Ф., Сайкин А.М. Исследование влияния условий эксплуатации карьерных самосвалов на загрязнение воздуха кабин водителей // Журнал автомобильных инженеров. - 2009. - № 4 (57). - С. 17-19.

17. Workplace exposure to diesel and gasoline engine exhausts and the risk of colorectal cancer in Canadian men / L. Kachuri, P.J. Villeneuve, M-É. Parent, K.C. Johnson // Environmental Health. - 2016. - Vol. 15, № 1. - P. 4-16. DOI.org/10.1186/s12940-016-0088-1

18. Taxell P., Santonen T. Diesel engine exhaust: basis for occupational exposure limit value // Toxicological Sciences. - 2017. Vol. 158, № 2. - P. 243-251. DOI.org/10.1093/toxsci/kfx110

19. Thiruvengadam A., Besch M., Carder D., Oshinuga A. Unregulated greenhouse gas and ammonia emissions from current technology heavy-duty vehicles // Journal of the Air \& Waste Management Association. - 2016. - Vol. 66, № 11. - P. 1045-1060. DOI: org/10.1080/10962247.2016.1158751 
20. Diesel motor emissions and lung cancer mortalityResults of the second follow-up of a cohort study in potash miners / A. Neumeyer-Gromen, O. Razum, N. Kersten, A, Seidler, H. Zeeb // International journal of cancer. - 2009. - Vol. 124, № 8. P. 1900-1906. DOI: org/10.1002/ijc. 24127

21. Occupational Exposure to Diesel and Gasoline Engine Exhausts and the Risk of Kidney Cancer in Canadian Men / C.E. Peters, M.É. Parent, S.A. Harris [et al.] // Annals of work exposures and health. - 2018. - Vol. 62, № 8. - P. 978-989. DOI.org/10.1093/annweh/wxy059

22. Osorio-Tejada J. L., Llera-Sastresa E., Scarpellini S. A multi-criteria sustainability assessment for biodiesel and liquefied natural gas as alternative fuels in transport systems // Journal of Natural Gas Science and Engineering. - 2017. - Vol. 42. - P. 169-186. DOI: org/10.1016/j.jngse.2017.02.046

23. Frey H. C. Trends in onroad transportation energy and emissions // Journal of the Air \& Waste Management Association. - 2018. - Vol. 68, № 6. - P. 514-563. DOI: $10.1080 / 10962247.2018 .1454357$

24. Greenhouse gas emissions from heavy-duty natural gas, hybrid, and conventional diesel on-road trucks during freight transport / D.C. Quiros, J. Smith, A. Thiruvengadam, T. Huai // Atmospheric Environment. - 2017. - Vol. 168. - P. 36-45. DOI.org/10.1016/j.atmosenv.2017.08.066

25. Emission Standards [Электронный ресурс]. - URL: https://www.dieselnet.com/standards/ (дата обращения: 19.08.2019).

26. EU: Nonroad Engines [Электронный ресурс]. - URL: https://www.dieselnet.com/standards/eu/nonroad. php\#intro (дата обращения: 19.08.2019).

27. ГОСТ Р 41.96-1999. Единообразные предписания, касающиеся двигателей с воспламенением от сжатия, предназначенных для установки на сельскохозяйственных и лесных тракторах и внедорожной технике, в отношении выброса вредных веществ этими двигателям: введ. 2001-01-01. М.: Изд-во стандартов, 2001. - 61 с.

28. ГОСТ Р 41.96-2005. Единообразные предписания, касающиеся вигателей с воспламенением от сжатия, предназначенных для установки на сельскохозяйственных и лесных тракторах и внедорожной технике, в отношении выброса вредных веществ этими двигателям: введ. 2008-01-01. М.: Стандартинформ, 2006. - 61 с.

29. ГОСТ Р 41.96-2011. Единообразные предписания, касающиеся двигателей с воспламенением от сжатия, предназначенных для установки на сельскохозяйственных и лесных тракторах и внедорожной технике, в отношении выброса вредных веществ этими двигателям: введ. 2013-01-03 взамен ГОСТ Р 41.96-2005. - М.: Стандартинформ, 2013. - 61 с.

30. Energy consumption and greenhouse gas emissions of diesel/LNG heavy-duty vehicle fleets in China based on a bottom-up model analysis / H. Song, X. Ou, J. Yuan, C.l. Wang // Energy. 2017. - Vol. 140. - P. 966-978. DOI: org/10.1016/j.energy.2017.09.011

31. The characteristics of greenhouse gas emissions from heavy-duty trucks in the Beijing-Tianjin-Hebei (BTH) region in
China / Y. Xing, H. Song, M. Yu [et al.] // Atmosphere. - 2016. Vol. 7, № 9. - P. 121-132. DOI: org/10.3390/atmos7090121

32. European Commission «Cutting emissions and cutting red tape: a new regulation for off-road engines» (2014). [Электронный pecypc]. - URL: http://europa.eu/rapid/pressrelease_IP-14-1044_en.htm (дата обращения: 19.08.2019).

33. European Parliament and Council «Regulation (EU) 2016/1628 of the European Parliament and of the Council of 14 September 2016 on requirements related to gaseaous and particulate pollution emission limits and type-approval for internal combustion engines for non-road mobile machinery» (2016). [Электронный pecypc]. - URL: http://eurlex.europa.eu/legal-content/EN/TXT/? uri = CELEX:32016R1628 (дата обращения: 19.08.2019).

34. Shao Z., Dallmann T. European stage $\mathrm{v}$ non-road emission standars [Электронный pecypc]. - URL: https:// theicct.org/publications/european-stage-v-non-road-emission-standards (дата обращения: 19.08.2019).

35. Characteristics of particle number and mass emissions during heavy-duty diesel truck parked active DPF regeneration in an ambient air dilution tunnel / S. Yoon, D.C. Quiros, H.A. Dwyer, J.F. Collins // Atmospheric Environment. - 2015. - Vol. 122. P. 58-64. DOI: org/10.1016/j.atmosenv.2015.09.032

36. Yamada H., Inomata S., Tanimoto H. Mechanisms of increased particle and VOC emissions during DPF active regeneration and practical emissions considering regeneration // Environmental science \& technology. - 2017. - Vol. 51, № 5. P. 2914-2923. DOI: org/10.1021/acs.est.6b05866

37. Чернецов Д.А. Токсичность отработавших газов дизелей и их антропогенное воздействие // Вопросы современной науки и практики. Университет им. В.И. Вернадского. - 2010. № 10-12. - С. 54-59.

38. European Commission, Climate action: Reducing the carbon content of transport fuels: press release. - Brussels, 2014.

39. Cottrell J. FPT Powertrain Technologies Stage V NRMM. 8 Integer Chicago; DEUTZ. Stage V ready (2015), \& RollsRoyce power systems AG. Rolls-Royce to exhibit MTU Stage V engines at bauma 2016 (2016). [Электронный ресурс]. - URL: http://www.oemoffhighway.com/press_release/12160037/rollsroyce-to-exhibit-mtu-stage-v-engines-at-bauma-201 (дата обращения: 19.08.2019).

40. Federal Institute for Occupational Safety and Health (BAuA). «Technische Regel für Gefahrstoffe 554» (2008) [Электронный ресурc]. - URL: http://www.baua.de/ de/Themen-von-AZ/Gefahrstoffe/TRGS/TRGS-554.html (дата обращения: 19.08.2019).

41. The Austrian Federal Ministry of Agriculture, Forestry, Environment and Water Management. «Verordnung über die Verwendung von mobilen technischen Einrichtungen, Maschinen und Geräten» (2015) [Электронный ресурc]. - URL: https://www. bmlfuw.gv.at/umwelt/luft-laerm-erkehr/luft/richtlinien/offroadvo.html (дата обращения: 19.08.2019).

42. The Inspectorate SZW [Электронный ресурс]. - URL: http://www.inspectieszw.nl (дата обращения: 19.08.2019).

Please cite this article in English as:

Khazin M.L. Environmental Standards around the World for Mining Machines and Equipment. Perm Journal of Petroleum and Mining Engineering, 2020, vol.20, no.3, pp.291-300. DOI: 10.15593/2712-8008/2020.3.9

Просьба ссылаться на эту статью в русскоязычных источниках следующим образом:

Хазин М.Л. Экологические стандарты стран мира для горных машин и оборудования // Недропользование. - 2020. T.20, №3. - C.291-300. DOI: 10.15593/2712-8008/2020.3.9 